\title{
Nutritional Status and Productive Components of Maize Fertilized With Sewage Sludge
}

\author{
Carlos Cesar Breda ${ }^{1}$, Renan Francisco Rimoldi Tavanti ${ }^{2}$, Onã da Silva Freddi ${ }^{1}$, Tauan Rimoldi Tavanti ${ }^{2}$, \\ Aline Regina Piedade ${ }^{3}$, Denise Mahl ${ }^{4}$, Iraê Amaral Guerrini ${ }^{5} \&$ Rogério Carlos Traballi $^{6}$ \\ ${ }^{1}$ Federal University of Mato Grosso, Sinop, MT, Brazil \\ ${ }^{2}$ São Paulo State University “Julio de Mesquita Filho”, Ilha Solteira, SP, Brazil \\ ${ }^{3}$ Federal University of Mato Grosso, Cuiabá, MT, Brazil \\ ${ }^{4}$ Maringá State University, Maringá, PR, Brazil \\ ${ }^{5}$ São Paulo State University “Julio de Mesquita Filho", Botucatu, SP, Brazil \\ ${ }^{6}$ Paulista University, São Paulo, SP, Brazil \\ Correspondence: Renan Francisco Rimoldi Tavanti, Department of Plant Protection, Rural Engineering and Soil, \\ São Paulo State University "Julio de Mesquita Filho" (UNESP), Passeio Monção, 226-Centro, Ilha Solteira, São \\ Paulo, Brazil. Tel: 55-(18)-3743-1142. E-mail: renan.tavanti91@gmail.com
}

Received: March 5, $2018 \quad$ Accepted: April 3, $2018 \quad$ Online Published: May 15, 2018
doi:10.5539/jas.v10n6p86
URL: https://doi.org/10.5539/jas.v10n6p86

\begin{abstract}
The response of crops to the application of biofertilizers in the soil is not yet well established. Therefore, we carried out this study with the objective of evaluating the productive potential of maize fertilized with doses of sewage sludge, comparing with the use of mineral fertilizer over four agricultural seasons. The experiment was conducted in a Red Dystroferric Nitosol (Ultisol) in a randomized block design and repeated measures in time. The treatments consisted of five doses of sewage sludge and one treatment using nitrogen, phosphorus and potassium in formulation. All fertilizations were carried out at maize sowing at four planting times (summer and $2^{\text {nd }}$ crop of $1^{\text {st }}$ agricultural year and, summer and $2^{\text {nd }}$ crop of $2^{\text {nd }}$ agricultural year) and replicates. The results showed a cumulative increase in the $\mathrm{P}, \mathrm{Ca}, \mathrm{Mg}$ and $\mathrm{Zn}$ leaf concentrations over the four seasons crops, when the sewage sludge was used in the 30 and $40 \mathrm{Mg} \mathrm{ha}^{-1}$ doses. However, reductions in plant height, weight and maize cob diameter, mass and grain yield were observed at the end of the last harvest. The treated sewage sludge is a viable alternative for maize fertilization in the first harvest, provides increases in grain yield in the order of 1.35 $\mathrm{Mg} \mathrm{ha}^{-1}$ and can be recommended instead of NPK mineral fertilizers in built-up fertility soils.
\end{abstract}

Keywords: Zea mays L., biofertilizer, environmental sustainability, waste in agriculture, nutrients.

\section{Introduction}

A major challenge for grain production in Brazil is to reduce the use of high greenhouse gas (GHG) emitting inputs, including fertilizers composed of chemical nitrogen and calcium carbonate, through the adoption of low carbon emissions (Guareschi et al., 2013; de Freitas Silva et al., 2014). These practices are seen as remedial measures in government conservation and environmental protection programs, such as the United Nations REDD+ (United Nations Collaborative Programme on Reducing Emissions from Deforestation and Forest Degradation in Developing Countries) and the ABC Plan (Low Carbon Agriculture Plan), implemented more than five years ago.

Due to these factors, in recent years there has been an increase in the use of biofertilizers and organic biostimulants in agriculture, which act as a source of nutrients and activators of the microbiota and the enzymatic activity of soil and plants.

Treated and processed sewage sludge, also known as biosolids, is one of the most widely used organic wastes for this purpose (Gonzaga et al., 2017). Several studies have demonstrated its efficiency in increasing crop productivity, among them Tejada et al. (2016), using sewage sludge treated as a source of nutrients for maize, reaching yields of up to $17 \mathrm{Mg} \mathrm{ha}^{-1}\left(\sim 283 \mathrm{sc} \mathrm{ha}^{-1}\right)$ when applied together with mineral fertilizer. 
However, in Brazil, the acquisition of sewage sludge treated and processed in large quantities is still a challenge, since only $45 \%$ of the population has a sewage network, with only $43 \%$ being submitted to correct treatments (SNSA, 2015). In addition, many localities still have their sewers disposed of in the open. The deficiency of the system of sanitary sewage in many municipalities has caused problems related to the deposition of these effluents in the water bodies (Carlson et al., 2013).

In order to understand this environmental problem, researchers from different areas of science have begun to show interest in studies on the use of sewage sludge in small and medium-sized rural properties, taking into account the economic and operational feasibility of agricultural systems (Cieślik et al., 2015). The options for domestic wastewater treatment or recovery involve numerous alternatives that can be complex and costly, or simple and low cost.

A simple alternative for the treatment and purification of domestic sewage can be done through decant boxes and filtering substrate with aquatic macrophytes. This project has already been funded by the São Paulo State Foundation for Research Support (FAPESP) and was developed by São Paulo State University (UNESP/FCA) to treat the household evictions generated by a small rural community of Lageado Farm in Botucatu county.

The system proposed in this station proved to be efficient in the treatment of sewage, according to reports by Guimarães and Conte (1997), Guimarães et al. (1999), and Leopoldo et al. (1999), and can be considered an excellent solution for the treatment of sewage generated in small rural communities. However, this system generates a new type of waste, which is the sewage sludge, which must have a correct destination.

Therefore, the initial proposal was the use of this waste as fertilizer, clarifying the doubts about the effects of sewage sludge on macro and micronutrient leaf concentrations and crop productivity over the years.

Thus, we carried out this study with the objective of evaluating the maize productive potential under doses of sewage sludge treated as fertilizer, comparing them with the NPK mineral fertilizer use during four agricultural crops.

\section{Method}

The study was carried out in Botucatu county, São Paulo, Brazil, in an area of the Experimental Lageado Farm of the Faculty of Agronomic Sciences (FCA) - UNESP, in the geographic coordinates $22^{\circ} 51^{\prime} 02^{\prime \prime} \mathrm{S}$ and $48^{\circ} 25^{\prime} 44^{\prime \prime} \mathrm{W}$, approximately $750 \mathrm{~m}$ of altitude. The climate of the region, according to the classification of Köppen-Geiger, is of type Cwa (humid subtropical) with two well defined seasons, humid summer and dry winter. Annual rainfall and temperatures are on average $1400 \mathrm{~mm}$ and $27^{\circ} \mathrm{C}$, respectively.

The soil of the site is a medium/clayey Dystroferric Red Nitosol (Ultisol, USD Soil taxonomy) with undulating relief. The soil fertility conditions in the respective layers of $0.00-0.10$ and $0.10-0.20 \mathrm{~m}$ are shown in Table 1 .

Table 1. Initial soil properties in the layers of $0.00-0.10$ and $0.10-0.20 \mathrm{~m}$

\begin{tabular}{|c|c|c|c|c|c|c|c|c|c|c|c|c|c|c|}
\hline \multirow{2}{*}{ Depth (m) } & \multirow{2}{*}{$\mathrm{pH}$} & \multirow{2}{*}{$\mathrm{OM}$} & \multirow{2}{*}{$\mathrm{Al}$} & \multirow{2}{*}{$\mathrm{H}+\mathrm{Al}$} & \multicolumn{5}{|c|}{ Macronutrients } & \multicolumn{5}{|c|}{ Micronutrients } \\
\hline & & & & & $\mathrm{P}$ & $\mathrm{K}$ & $\mathrm{Ca}$ & $\mathrm{Mg}$ & $\mathrm{S}$ & B & $\mathrm{Cu}$ & $\mathrm{Fe}$ & $\mathrm{Mn}$ & $\mathrm{Zn}$ \\
\hline $0.00-0.10$ & 4.8 & 23 & 1 & 24 & 16 & 4.4 & 15 & 6 & 7 & 0.10 & 4.6 & 37 & 13.8 & 1.0 \\
\hline $0.10-0.20$ & 4.4 & 22 & 2 & 28 & 5 & 2.5 & 11 & 4 & 8 & 0.10 & 5.0 & 51 & 18.3 & 0.5 \\
\hline
\end{tabular}

Note. $\mathrm{pH}\left(\mathrm{CaCl}_{2}\right) ; \mathrm{OM}$ corresponds to soil organic matter $\left(\mathrm{g} \mathrm{dm}^{-3}\right) ; \mathrm{K}, \mathrm{Ca}, \mathrm{Mg}, \mathrm{S}, \mathrm{Al}, \mathrm{H}+\mathrm{Al}\left(\mathrm{mmol}_{\mathrm{c}} \mathrm{dm}^{-3}\right) ; \mathrm{P}, \mathrm{B}$, $\mathrm{Cu}, \mathrm{Fe}, \mathrm{Mn}, \mathrm{Zn}\left(\mathrm{mg} \mathrm{dm}^{-3}\right)$. P concentration determined by the resin method; $\mathrm{Cu}, \mathrm{Fe}, \mathrm{Mn}$ and $\mathrm{Zn}$ by the DTPA method and; B by hot water method.

The experiment was conducted in a randomized complete block design with repeated measures in time, being 5 fertilization treatments: $0,10,20,30$ and $40 \mathrm{Mg} \mathrm{ha}^{-1}$ of treated sewage sludge and $0.5 \mathrm{Mg} \mathrm{ha}^{-1}$ of the formulation NPK 04-14-08 $\left(8.70 \mathrm{~kg}\right.$ of urea $46 \% \mathrm{~N} ; 6.09 \mathrm{~kg}$ of triple superphosphate $41 \% \mathrm{P}_{2} \mathrm{O}_{5} ; 71.88 \mathrm{~kg}$ of simple superphosphate $16 \% \mathrm{P}_{2} \mathrm{O}_{5}$ and; $13.33 \mathrm{~kg}$ of $\mathrm{KCl} 60 \% \mathrm{~K}_{2} \mathrm{O}$ ), both carried out in maize sowing in 4 planting seasons: summer and second crop of the first agricultural year and summer and second crop of the second agricultural year, even with 4 replicates. Fertilization and sowing dates and climatic conditions during the 4 seasons crops are shown in Figure 1. 


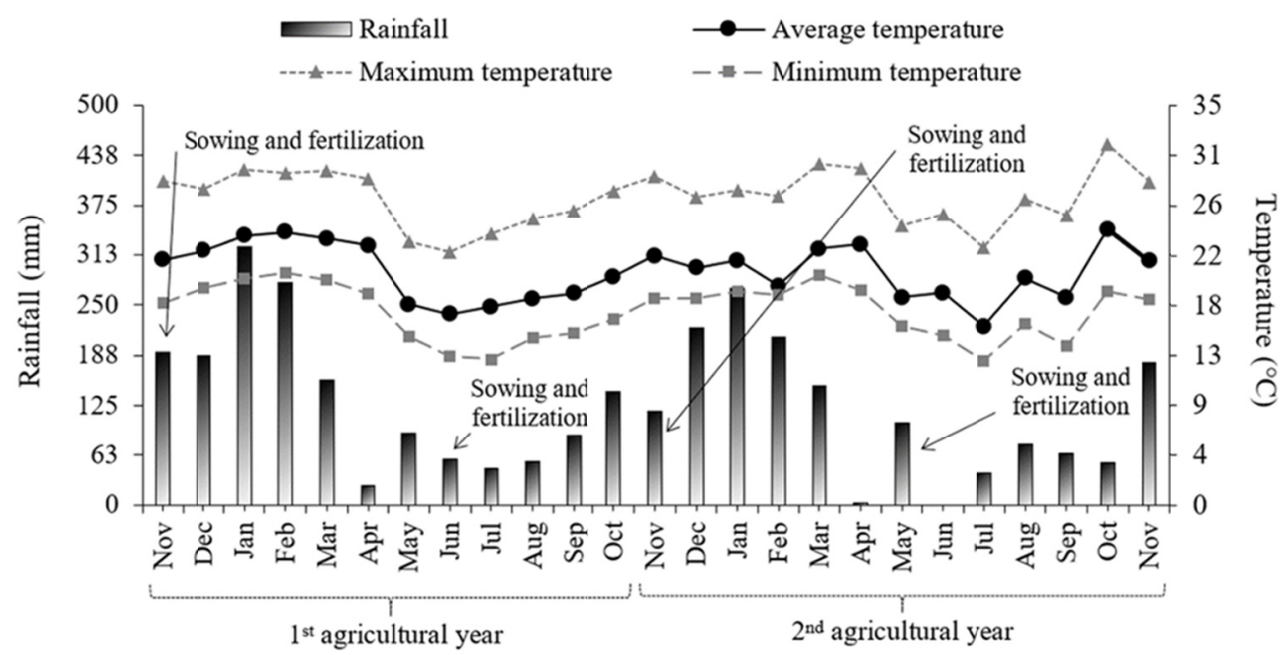

Figure 1. Maximum, minimum and average temperature and rainfall during summer and second crop of the first and second agricultural year. Data provided by the meteorological station of the Department of Soils and Environmental Resources of UNESP

Thus, the statistical model that describes the design was:

$$
Y_{i j k}=\mu+t_{i}+b_{j}+e_{i j}+\gamma_{k}+(t \times \gamma)_{i k}+e_{i j k}
$$

where: $Y_{i j k}$ is the value of the response variable referring to the i-th treatment and k-th time in the $\mathrm{j}$-th block; $\mu$ the general mean; $t_{i}$ the effect of the i-th treatment; $b_{j}$ the effect of the $\mathrm{j}$-th block; $e_{i j}$ random variation linked to the first level i-th treatment and j-th block; $\gamma_{k}$ the effect of the k-th sowing season; $(t \times \gamma)_{i k}$ interaction between $\mathrm{i}$-th treatment and k-th epoch; $e_{i j k}$ random variation linked to the second level i-th treatment, $\mathrm{j}$-th block and $\mathrm{k}$-th time.

The sludge used was obtained from the Experimental Station for the Treatment of Domestic Effluents from Lageado Farm (ETL) (Figure 2), which is located in the vicinity of colonies inhabited by approximately 60 people.

The treatment of the sewage in this place is done by the passage of the domestic waste in decant boxes, boxes with crushed stone beds and boxes of phyto-pedological system, which consists in the combination of filtering substrate with plants of Junco (Juncus sellovianus).

Thus, we consider sewage sludge, all the solid material retained in the settling boxes, and used as nutrient source in the present study (Figure 2). 
(A)

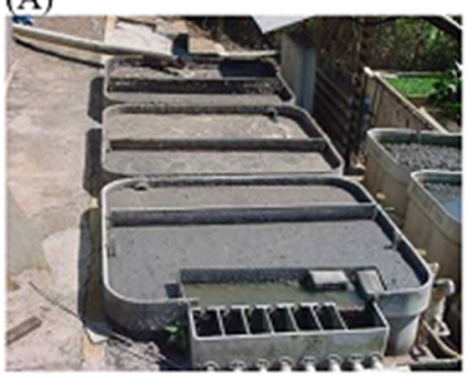

(D)

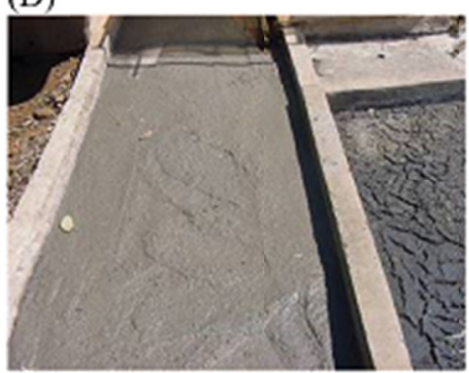

(B)

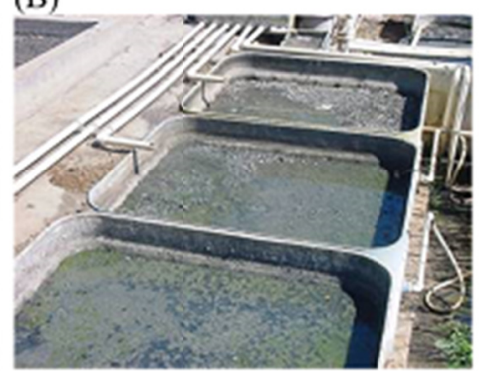

(E)

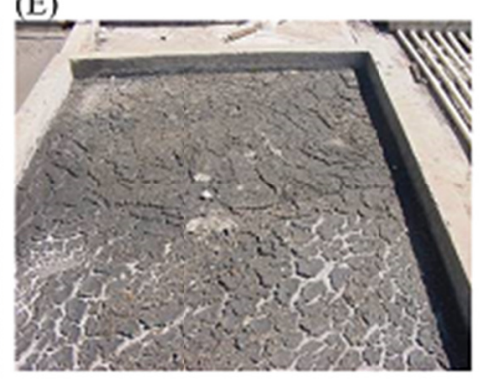

(C)

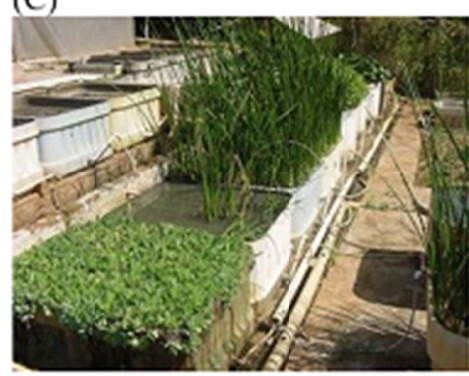

(F)

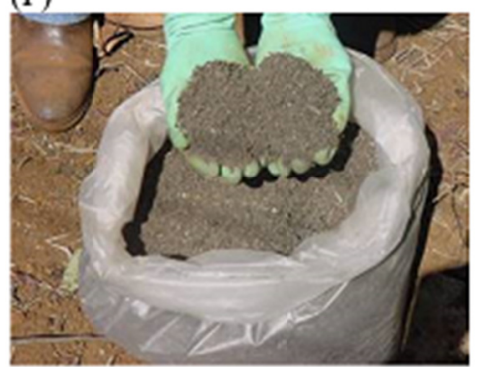

Figure 2. (A) settling boxes, (B) boxes with crushed stone bed, (C) phyto-pedological system boxes, (D) collected sludge, (E) dry sludge for grinding, $(\mathrm{F})$ for fertilization

The sludge was removed periodically and placed in a specific place for drying in the heat of the sun, later transferred to a place protected by plastic tarpaulin in order to avoid the action of the rains and to decrease the time of drying. After complete drying, the sludge was sieved to separate unwanted materials (plastics, metals, papers, among others) and finally ground.

At each seeding season samples of the sewage sludge were collected to characterize its chemical compounds, resulting in the values presented in Table 2.

The sewage sludge was separated into plastic bags with the quantities for each treatment, and then it was manually dispersed throughout the plot area in order to give the greatest uniformity. After spreading, the sludge was incorporated into the soil at a depth of $0.20 \mathrm{~m}$ with the aid of a small rotating hoe coupled to a Tobata tractor.

In maize cultivation, the spacing of $0.75 \mathrm{~m}$ between rows with 5 plants per meter was used. Each useful line had 15 plants, but only the data referring to the 11 central plants were considered for analysis, since two plants of each end were also taken as border, thus, it was considered with a useful area of $12.15 \mathrm{~m}^{2}$.

The management practices of the maize followed the technical recommendations of cultivation and were made homogeneously throughout the experimental area.

To determine the biometric parameters of maize, at the end of each crop season, all plants of the three central lines of each experimental unit were collected. The plant height $(\mathrm{PH})$, number of leaves $(\mathrm{NL})$, stem diameter (SD), maize cob length (ML), maize cob weight without straw (MW), maize cob diameter (MD), number of grains per maize cob (NG), mass of 100 grains (GM) and grain yield (GY) with values adjusted for 13\% moisture conditions.

The concentration of nitrogen $(\mathrm{N})$, phosphorus $(\mathrm{P})$, potassium $(\mathrm{K})$, calcium $(\mathrm{Ca})$, magnesium $(\mathrm{Mg})$, sulfur $(\mathrm{S})$, boron $(\mathrm{B})$, cupper $(\mathrm{Cu})$, iron $(\mathrm{Fe})$, manganese $(\mathrm{Mn})$ and zinc $(\mathrm{Zn})$ were determined on the diagnostic leafs (leaf opposite to the ear), at the moment when $50 \%$ of the plants in the area emitted the tassel, according to the methodology proposed by Malavolta et al. (1997). 
Table 2. Chemical characteristics of sewage sludge collected during the respective maize planting season

\begin{tabular}{|c|c|c|c|c|}
\hline \multirow{3}{*}{ Properties $^{1}$} & \multicolumn{4}{|c|}{ Collected sawage sludge } \\
\hline & \multicolumn{2}{|c|}{$1^{\text {st }}$ agricultural year } & \multicolumn{2}{|c|}{$2^{\text {nd }}$ agricultural year } \\
\hline & Summer & $2^{\text {nd }}$ crop & Summer & $2^{\text {nd }}$ crop \\
\hline $\mathrm{pH} \mathrm{CaCl}{ }_{2}$ & 5.8 & 7.2 & 6.0 & 6.4 \\
\hline $\mathrm{OM}$ & 66 & 32 & 69 & 57 \\
\hline $\mathrm{C} / \mathrm{N}$ & $10 / 1$ & $4 / 1$ & $9 / 1$ & $8 / 1$ \\
\hline Total N & 3.5 & 4.3 & 7.4 & 4.2 \\
\hline Total $\mathrm{P}_{2} \mathrm{O}_{5}$ & 1.3 & 1.3 & 2.6 & 1.6 \\
\hline Total $\mathrm{K}_{2} \mathrm{O}$ & 0.5 & 0.2 & 0.2 & 0.2 \\
\hline Total C & 36.8 & 17.8 & 38.3 & 31.7 \\
\hline Total Ca & 2.3 & 2.3 & 2.2 & 2.2 \\
\hline Total Mg & 0.2 & 0.2 & 0.2 & 0.2 \\
\hline Total S & 0.5 & 0.8 & 1.0 & 0.5 \\
\hline Total Zn & 537 & 522 & 920 & 600 \\
\hline Total Mn & 138 & 160 & 200 & 198 \\
\hline Total $\mathrm{Cu}$ & 81 & 132 & 200 & 126 \\
\hline Total Fe & 23333 & 21600 & 29150 & 27750 \\
\hline Total $\mathrm{Na}$ & 814 & 800 & 718 & 554 \\
\hline
\end{tabular}

Note. OM: corresponds to organic matter $\left(\mathrm{g} \mathrm{kg}^{-1}\right)$, Total $\mathrm{N}, \mathrm{P}_{2} \mathrm{O}_{5}, \mathrm{~K}_{2} \mathrm{O}, \mathrm{C}, \mathrm{Ca}, \mathrm{Mg}$, and $\mathrm{S}\left(\mathrm{g} \mathrm{kg}^{-1}\right)$; Total $\mathrm{Zn}, \mathrm{Mn}$, $\mathrm{Cu}, \mathrm{Fe}$, and $\mathrm{Na}\left(\mathrm{mg} \mathrm{kg}^{-1}\right)$.

The data were submitted to the normality test of Shapiro and Wilk $(1965)(p<0.05)$ and, in the presence of outliers, those with 2.5 times higher values than the interquartile range were removed, respecting the $10 \%$ limit of the total of observations in the plots. Subsequently, the normal data were submitted to analysis of variance by the F test $(\mathrm{p}<0.05)$. The main factor was fertilization with treated sewage sludge and formulated NPK fertilizer and, as a secondary factor, maize sowing times.

The sowing time factor was submitted to the Mauchly (1940) test, in order to verify the sphericity or circularity of the covariance matrix between times (number of repeated measures), that is, the equality of the variances between pairs of errors. When the test was non-significant $(p>0.05)$, the sphericity of the covariance matrix was verified and the experiment could be analyzed as a subdivide plot. When significant $(\mathrm{p}<0.05)$, the sphericity assumption was violated with the F-value positively biased making it invalid and increasing the risk of a Type I error. To overcome this problem, an adjustment factor "epsilon" was applied, to arrive at a corrected F statistic, that is, Greenhouse and Geisser (1959) statistic, in which the reduced degrees of freedom (df) of the times factor were calculated to reflect the fact that the hypotheses are correlated and not independent according to Equations 2,3 and $4:$

$$
\begin{gathered}
\varepsilon=1 /(k-1) \\
d f_{\text {(time/condition) }}=\varepsilon \times(k-1) \\
d f_{\text {error }}=\varepsilon \times(k-1) \times(n-1)
\end{gathered}
$$

Where, $\varepsilon$ is the epsilon value, $k$ is the number of repeated measures and, $n$ number of observations.

When $\mathrm{F}$ was significant, the response variables were compared by the standard error of the mean and, specifically for GY, polynomial regression analysis was performed by adopting the highest coefficient of determination $\left(R^{2}\right)$, the smallest sum of squares errors and the significance of the parameters of the equation $(\mathrm{p}<$ $0.05)$.

In addition, the principal components analysis was performed in order to verify the set of attributes that explained most of the maize grain yield variability. For this, data were standardized for mean 0 and variance 1 and then submitted to principal component analysis (PCA), considering only the main components (PC's) with eigenvalues greater than 1 (Trevisan et al., 2017). 


\section{Results}

In the characterization of macro and $\mathrm{Mn}$ and $\mathrm{Zn}$ foliar concentrations of maize, was used the classification proposed by van Raij et al. (1996) for conditions of the state of São Paulo, Brazil. Thus, a significant effect of fertilization of sewage sludge (SS) and seasons crops on maize P, K, S, Mn and $\mathrm{Zn}$ leaf concentrations was observed (Table 1B).

It is observed that sewage sludge supplied $\mathrm{N}$ requirements in maize, maintaining leaf at adequate levels, above $27.5 \mathrm{~g} \mathrm{~kg}^{-1}$ in practically all crop seasons (Figure 3). These results were maintained until the second agricultural year with fertilizations of 10,20 and $30 \mathrm{Mg} \mathrm{ha}^{-1}$ of SS. At the end of the second agricultural year the control treatment that did not receive any type of fertilization presented a $\mathrm{N}$-foliar concentration of $18.67 \mathrm{~g} \mathrm{~kg}^{-1}$.

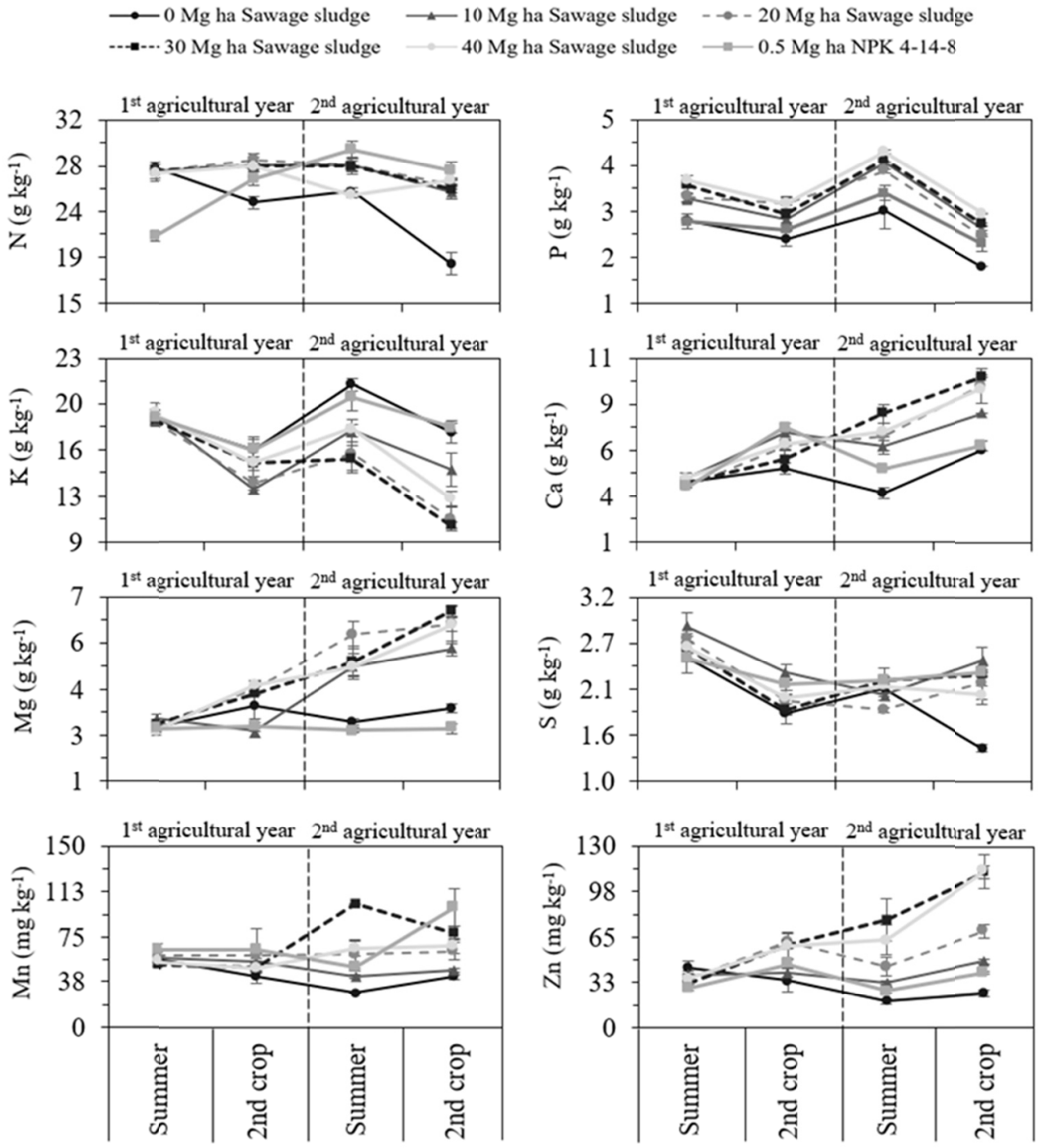

Figure 3. Foliar macro and micronutrient of maize after fertilization with sewage sludge

The control treatment of zero $\mathrm{Mg} \mathrm{ha}{ }^{-1}$ of sewage sludge presented leaf content of P below $2 \mathrm{~g} \mathrm{~kg}^{-1}$ and S below $1.5 \mathrm{~g} \mathrm{~kg}^{-1}$, being considered insufficients (Figure 3). The highest leaf $\mathrm{P}$ concentration was observed in the first crop of the second agricultural year for the treatment with $40 \mathrm{Mg} \mathrm{ha}^{-1}$ of sewage sludge. Under these conditions, there was accumulation of $\mathrm{P}$ of up to $4.30 \mathrm{~g} \mathrm{~kg}^{-1}$ being the time that most contributed to the accumulation of this nutrient in all the treatments. This fact can be justified by the chemical characteristics of the sewage sludge collected at this period, in which the $\mathrm{P}_{2} \mathrm{O}_{5}$ content was higher in relation to the other crops, with a total content of $2.6 \mathrm{~g} \mathrm{~kg}^{-1}$ (Table 2). 
As for leaf $\mathrm{K}$ concentrations, treatments with zero $\mathrm{Mg} \mathrm{ha}^{-1}$ of SS and $0.5 \mathrm{Mg} \mathrm{ha}^{-1}$ of NPK formulation were observed in the first crop of the second agricultural year with the highest accumulations, with 21 and $20 \mathrm{~g} \mathrm{~kg}^{-1}$, respectively. In the following season, the lowest accumulation among the proposed treatments was 13 and $16 \mathrm{~g}$ $\mathrm{kg}^{-1}$, all of them below the critical range of sufficiency of $17 \mathrm{~g} \mathrm{~kg}^{-1}$.

Foliar $\mathrm{Ca}$ and $\mathrm{Mg}$ concentrations increased over time with consecutive applications of 20,30 and $40 \mathrm{Mg} \mathrm{ha}^{-1} \mathrm{SS}$. At the end of the second crop of the second year, it was observed that the $\mathrm{Ca}$ and $\mathrm{Mg}$ values were above the maize sufficiency range, which are 8 and $5 \mathrm{~g} \mathrm{~kg}^{-1}$, respectively. Ca concentrations in the leaves increased by 49.0 , 60.0 and $49.3 \%$ in relation to the control, while for $\mathrm{Mg}$ the leaf concentrations were higher 125.0, 143.7 and $125.9 \%$, respectively.

$\mathrm{Mn}$ and $\mathrm{Zn}$ cationic micronutrient concentrations were higher in treatments that received 30 and $40 \mathrm{Mg} \mathrm{ha}^{-1}$ of sludge, with values up to $102.67 \mathrm{mg} \mathrm{kg}^{-1}$ for $\mathrm{Mn}$ and $112.33 \mathrm{mg} \mathrm{kg}^{-1}$ for $\mathrm{Zn}$. Only in the second crop of the second agricultural year did the $\mathrm{Zn}$ be above the critical level of the maize.

There was a significant effect of fertilization of sewage sludge (SS) and sowing times (T) on maize biometric parameters (Table 2B). Successive applications of sewage sludge provided a decrease in leaf number (NL), ear length (ML) and mass of 100 grains (GM). It was observed at the end of the second agricultural year that the maize plants had on average approximately 13 leaves, ears with $16 \mathrm{~cm}$ and 100 grains weighing around $3.5 \mathrm{~g}$. On the other hand, the best responses to sewage sludge fertilization were observed in the first and second crop of the first agricultural year, with GM values up to $6.52 \mathrm{~g}$, ML up to $17.5 \mathrm{~cm}$ and NL of 15 , for the 30 and $40 \mathrm{Mg} \mathrm{ha}^{-1}$, respectively. It was also observed that these doses generated increment of $4.17 \mathrm{~cm}$ in $\mathrm{ML}$ and $4.49 \mathrm{~g}$ for GM in relation to the control in the last harvest.

For plant height (PH) and stem diameter (SD), the best responses were observed in the first and second crops of the first cropping year, in which the maximum expression was $216 \mathrm{~cm}$ and $2.7 \mathrm{~cm}$, respectively, with application of $40 \mathrm{Mg} \mathrm{ha}^{-1}$ of sewage sludge. In this condition, there was an increase of up to $21 \mathrm{~cm}$ in $\mathrm{PH}$ and $0.9 \mathrm{~cm}$ in SD relative to the control.

The productive components of maize cob diameter (MD) and number of grains per maize cob (NG) were positively influenced by the successive fertilizations with sewage sludge until the second crop of the first agricultural year. Treatments that received $40 \mathrm{Mg} \mathrm{ha}^{-1}$ of sludge presented the best responses, with $51.3 \mathrm{~mm}$ of $\mathrm{MD}$ and 576 grains per maize cob.

Regarding grain yield (GY), it was observed a higher response in the first crop of the first agricultural year with $10.95 \mathrm{Mg} \mathrm{ha}^{-1}$ at the dose of $20 \mathrm{Mg} \mathrm{ha}^{-1}$ of sludge (Figure 5). Soon after maize it suffered significant reductions in GY in all treatments, probably due to the exhaustion of nutrient reserves available in the soil and to depend only on the nutrients provided by the fertilizations proposed in the treatments. Thus, the GY of maize in the later harvests using $20 \mathrm{Mg} \mathrm{ha}^{-1}$ of SS were 7.1, 7.55 and $6.57 \mathrm{Mg} \mathrm{ha}^{-1}$, respectively.

Based on the polynomial regression analysis, it was verified that the yield of $11.06 \mathrm{Mg} \mathrm{ha}^{-1}$ can be obtained with application of $23.68 \mathrm{Mg} \mathrm{ha}^{-1}$ of sludge, considering the first crop of the first agricultural year. In the other years, productivity tends to be lower even with increasing doses of sludge, especially when this residue becomes the only source of nutrients for the crop. This is mainly due to the imbalance of elements that the sewage sludge presents.

The sewage sludge is generally rich in organic matter, macro and micronutrients, suggesting the possibility of its use in agriculture as fertilizer and soil conditioner. However, unhygienic sewage sludge may present problems related to pathogens and heavy metals. Depending on their composition, their characteristics may limit their employment in agriculture. Although the concentration of heavy metals in this study has not been evaluated, the results of low productivity may be correlated with the accumulation of toxic elements in plants. 


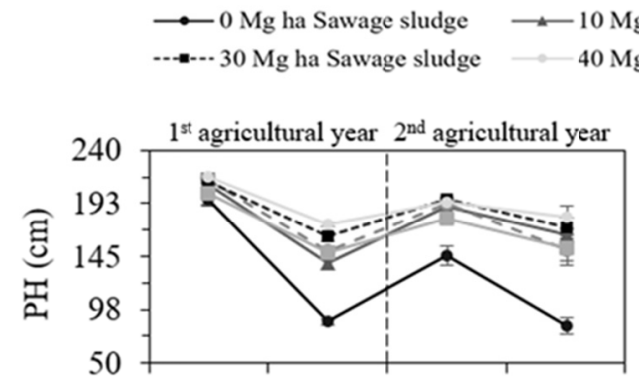

$0 \mathrm{Mg}$ ha Sawage sludge $\quad-\rightarrow-20 \mathrm{Mg}$ ha Sawage sludge

Mg ha Sawage sludge $\quad-0.5 \mathrm{Mg}$ ha NPK 4-14-8
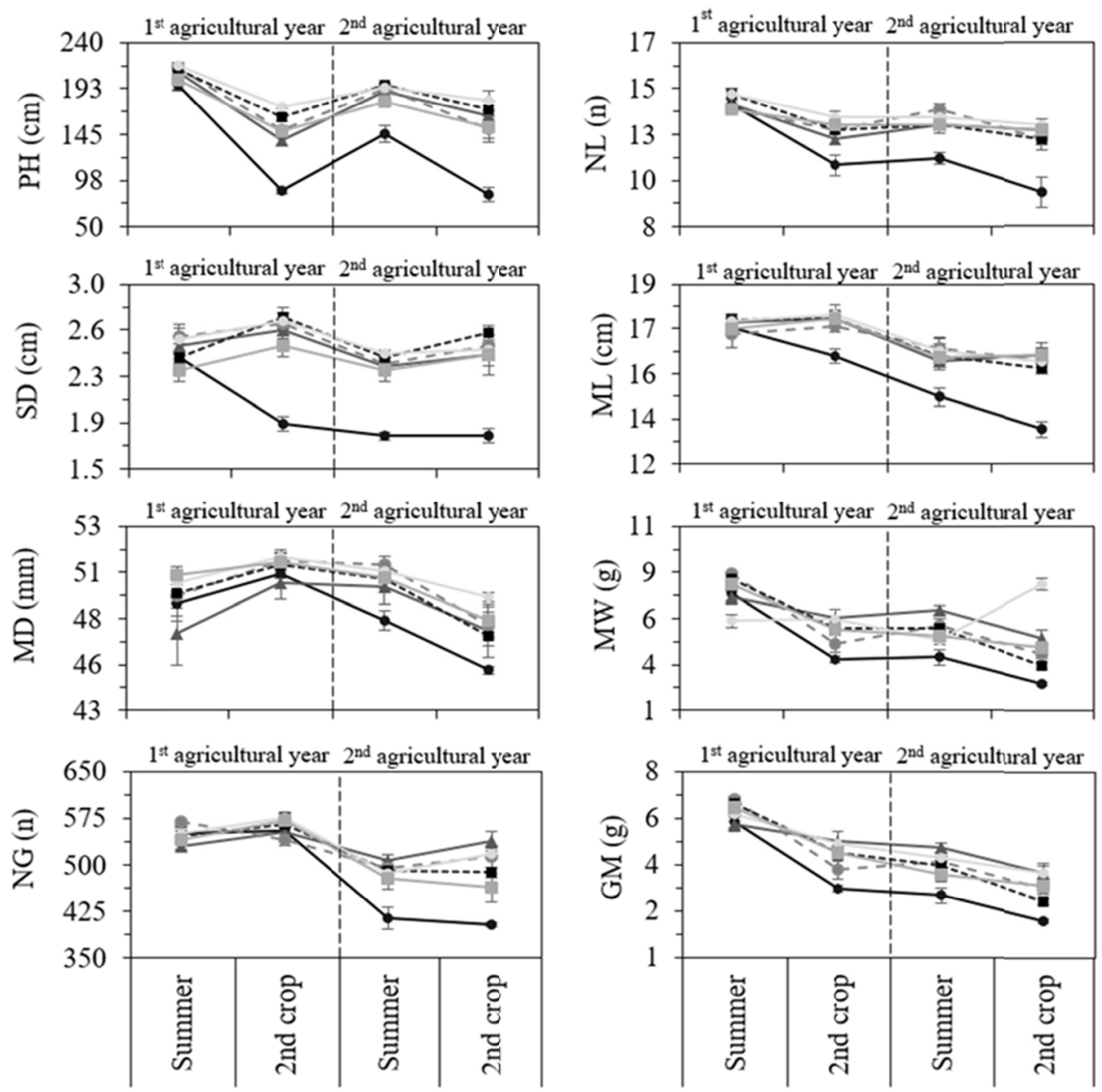

Figure 4. Biometric parameters of maize after fertilization with sewage sludge in the first and second agricultural years

(A)

(B)
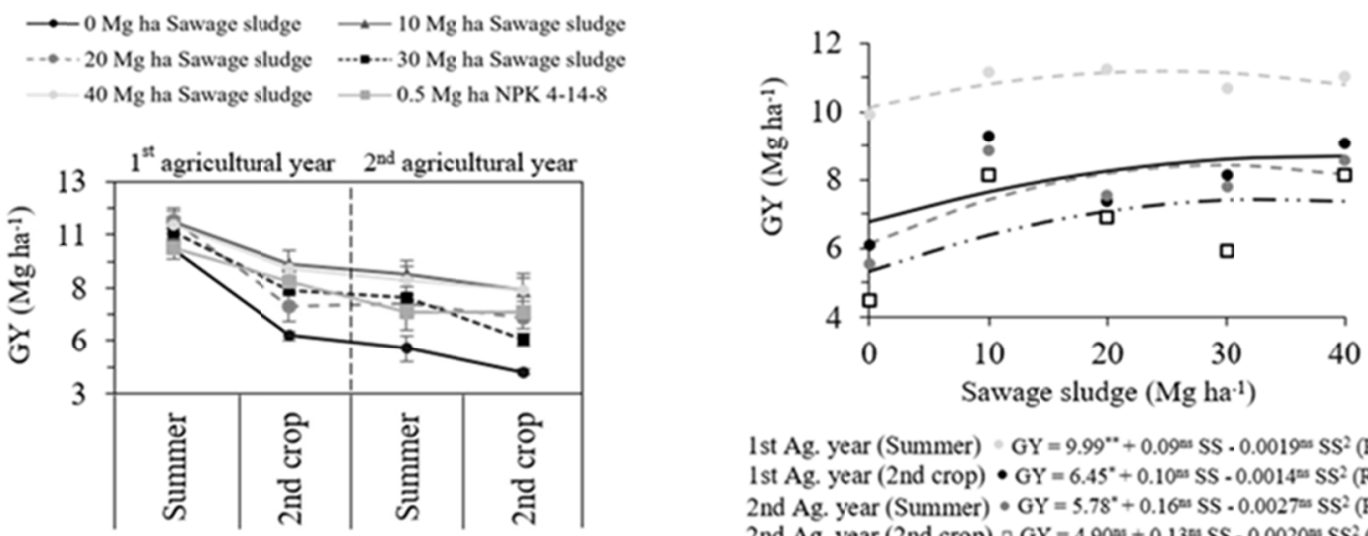

1st Ag. year (Summer) $* \mathrm{GY}=9.99^{* *}+0.09^{\mathrm{mat}} \mathrm{SS} \cdot 0.0019^{a n} \mathrm{SS}^{2}\left(\mathrm{R}^{2}=0.62^{\circ}\right)$ 1st Ag. year (2nd crop) $\bullet \mathrm{GY}=6.45^{*}+0.10^{\mathrm{mat}} \mathrm{SS} \cdot 0.0014^{\mathrm{ms}} \mathrm{SS}^{2}\left(\mathrm{R}^{2}=0.37^{\circ}\right)$ 2nd Ag. year (Summer) $\bullet \mathrm{GY}=5.78^{*}+0.16^{\mathrm{mat} S S} \cdot 0.0027^{\mathrm{mas}} \mathrm{SS}^{2}\left(\mathrm{R}^{2}=0.51^{\circ}\right)$ 2nd Ag. year (2nd crop) $\circ \mathrm{GY}=4.90^{\mathrm{ms}}+0.13^{\mathrm{ma}} \mathrm{SS}-0.0020^{\mathrm{m}} \mathrm{SS}^{2}\left(\mathrm{R}^{2}=0.32^{\circ}\right)$

Figure 5. (A) Effect of fertilization on maize grain yield during crop seasons; (B) maize performance on grain yield as a function of sewage sludge doses; *, ** and ns correspond respectively to significance at 0.05 and 0.01 of probability by the $t$ test and not significant 
Regarding the principal component analysis (PCA), it extracted 5 components (PCs) with eigenvectors between 7.18 and 1.32, representing $78.08 \%$ of all variability in the area (Table 3). Among the attributes correlated in PC1, GY was positively correlated with $\mathrm{PH}, \mathrm{NL}, \mathrm{MW}, \mathrm{ML}, \mathrm{NG}, \mathrm{GM}$, and $\mathrm{N}, \mathrm{P}, \mathrm{S}$ and $\mathrm{Cu}$ leaf concentrations, and negatively correlated with $\mathrm{Fe}$ and $\mathrm{Ca}$ leaf concentrations. In PC2 a positive correlation was observed for SD, and $\mathrm{Zn}, \mathrm{Mg}$ and negatively for $\mathrm{K}$ leaf concentrations.

Table 3. Summary of the main components of the multivariate analysis of biometric parameters of maize and nutritional status after fertilization with sewage sludge in four crop seasons

\begin{tabular}{|c|c|c|c|c|c|}
\hline Principal component & PC1 & PC2 & PC3 & PC4 & PC5 \\
\hline Eigenvalue & 6.97 & 3.02 & 1.84 & 1.54 & 1.31 \\
\hline Explained variance (\%) & 36.67 & 15.94 & 9.70 & 8.12 & 6.93 \\
\hline Variable & \multicolumn{5}{|l|}{ Correlation } \\
\hline \multicolumn{6}{|l|}{ Biometric parameters } \\
\hline Plant height & $0.80 *$ & 0.12 & -0.44 & 0.17 & -0.04 \\
\hline Number of leaves & $0.83 *$ & 0.19 & -0.20 & 0.13 & 0.09 \\
\hline Stem diameter & 0.43 & $0.69 *$ & 0.05 & 0.06 & 0.25 \\
\hline Maize cob weight & $0.92 *$ & -0.08 & 0.01 & 0.07 & -0.10 \\
\hline Maize cob lenght & $0.73 *$ & 0.38 & 0.36 & -0.14 & 0.13 \\
\hline Maize cob diameter & 0.39 & 0.34 & 0.01 & $-0.73 *$ & 0.01 \\
\hline Number of grais in maize cob & 0.60 & 0.38 & $0.54 *$ & -0.07 & -0.20 \\
\hline One hundred grain mass & $0.93 *$ & -0.05 & 0.12 & 0.06 & -0.11 \\
\hline Grain yield & $0.87 *$ & 0.03 & 0.11 & 0.16 & -0.10 \\
\hline \multicolumn{6}{|l|}{ Plant nutrition } \\
\hline Nitrogen & $0.56 *$ & 0.32 & -0.17 & -0.25 & 0.30 \\
\hline Phosphorus & $0.53 *$ & 0.12 & $-0.65 *$ & -0.27 & -0.21 \\
\hline Potassium & 0.40 & $-0.74 *$ & -0.11 & -0.17 & 0.20 \\
\hline Calcium & $-0.53 *$ & 0.42 & 0.20 & -0.02 & -0.34 \\
\hline Magnesium & -0.45 & $0.63 *$ & -0.44 & 0.13 & -0.30 \\
\hline Sulfur & $0.62 *$ & -0.04 & -0.07 & $0.52 *$ & 0.06 \\
\hline Boron & 0.49 & -0.35 & 0.10 & 0.48 & -0.29 \\
\hline Cupper & $0.67 *$ & -0.01 & $0.52 *$ & 0.05 & -0.24 \\
\hline Iron & $-0.65 *$ & 0.24 & 0.39 & 0.23 & 0.17 \\
\hline Manganese & -0.12 & 0.16 & 0.00 & 0.31 & $0.78 *$ \\
\hline Zinc & -0.27 & $0.80 *$ & -0.18 & 0.25 & -0.08 \\
\hline
\end{tabular}

Note. Correlations considered in the interpretation of the main components.

By the biplot graph between PC1 and PC2, it is possible to observe the condition of the proposed treatments against the correlations obtained in the PCA (Figure 6). The treatments with 10, 20, 30 and $40 \mathrm{Mg} \mathrm{ha}^{-1}$ of SS are closer to the group of variables that correspond to the biometric and productive parameters of maize, such as $\mathrm{PH}$, $\mathrm{NL}, \mathrm{MW}, \mathrm{GY}$, indicating, in this case, that the overall average grain yield (in the 4 harvests) was higher for these treatments, when compared to the control treatments $0 \mathrm{Mg} \mathrm{ha}^{-1}$ of SS and $0.5 \mathrm{Mg} \mathrm{ha}^{-1}$ of NPK.

Concerning the arrangement of treatments of foliar nutrients, it was observed that fertilizations with sewage sludge $\left(10,20,30\right.$ and $\left.40 \mathrm{Mg} \mathrm{ha}^{-1}\right)$ were predominant in the supply of $\mathrm{N}, \mathrm{P}, \mathrm{S}$ and $\mathrm{Cu}$, correlated together with the maize biometric parameters (Figure 6).

The correlation values obtained for $\mathrm{Ca}, \mathrm{Mg}, \mathrm{Fe}$ and $\mathrm{K}$ indicate that treatments zero $\mathrm{Mg}^{-1} \mathrm{ha}^{-1}$ of SS and $0.5 \mathrm{Mg}$ $\mathrm{ha}^{-1}$ NPK were favored (Figure 6). However, these treatments present scores that are far from biometric and productive parameters of maize, indicating low grain yield when compared to other treatments. 


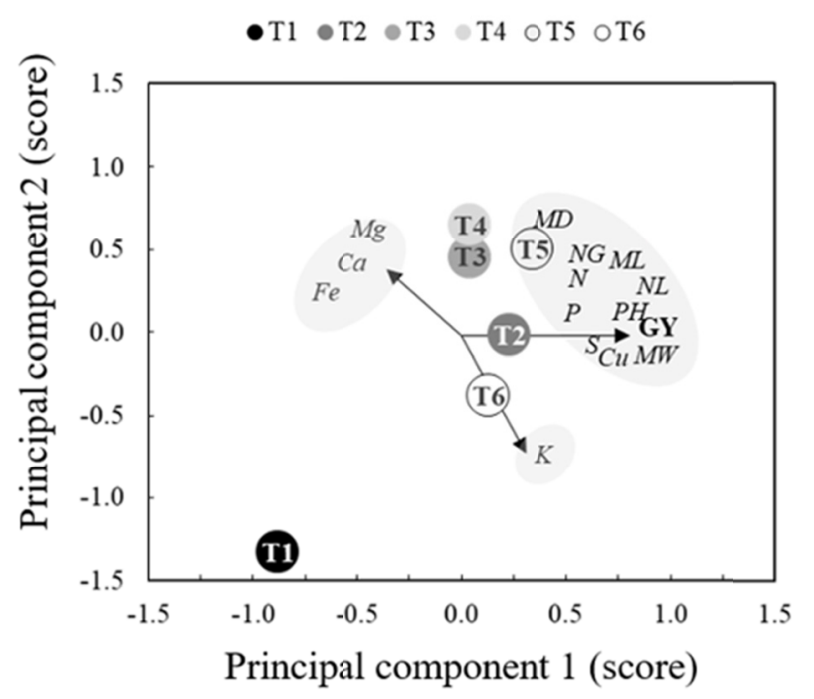

Figure 6. Biplot graph between the principal components 1 and 2 with treatments represented by $\mathrm{T} 1: \mathrm{zero} \mathrm{Mg}$ ha $^{-1}$ sewage sludge, T2: $10 \mathrm{Mg} \mathrm{ha}^{-1}$ sewage sludge, T3: $20 \mathrm{Mg} \mathrm{ha}^{-1}$ sewage sludge, T4: $30 \mathrm{Mg}^{-1}$ sewage sludge, T5: $40 \mathrm{Mg} \mathrm{ha}^{-1}$ sewage sludge, and T6: $0.5 \mathrm{Mg} \mathrm{ha}^{-1} \mathrm{NPK}$

\section{Discussion}

The foliar concentrations of $\mathrm{N}$ in maize did not follow a cumulative pattern in the treatments proposed during the crop seasons (Figure 3). This can be justified by the high mobility of this nutrient in the soil, in which leaves no remnants for the later crops. Given the importance of $\mathrm{N}$ fertilization for maize, it is recommended that be applied to the soil, or via irrigation water, when the plants have four to eight well-developed leaves (van Raij et al., 1996). With this, it extends the possibility of the practice of fertilization in topdressing with treated sewage sludge, which can be a profitable and interesting alternative.

The leaf concentrations of $\mathrm{P}$ and $\mathrm{S}$ were at adequate levels for most of the evaluated treatments. Except for the second crop of the second agricultural year, the control of zero $\mathrm{Mg} \mathrm{ha}^{-1}$. We must consider the importance of phosphate fertilization in Brazilian soils due to its low availability. Thus, chemical analysis of the sewage sludge is necessary, in order to check the need to complement the levels of $\mathrm{P}$ with mineral fertilizer.

The results obtained for the $\mathrm{K}$ content in leaves can be justified by van Raij et al. (1996), who report that the need for $\mathrm{K}_{2} \mathrm{O}$ to produce $10 \mathrm{Mg} \mathrm{ha}^{-1}$ of maize in soil similar to that of the experimental area is $40 \mathrm{~kg} \mathrm{ha}^{-1}$ at sowing. Thus, $\mathrm{K}$ requirements could not be met by SS fertilization, even at the highest dose of $40 \mathrm{Mg} \mathrm{ha}^{-1}$, and a sub-dosage of this nutrient occurred in the second harvest of the first year. This is due to the low amounts of $\mathrm{K}$ in sewage sludge, since this nutrient is easily loaded by the liquid phase due to its high solubility, as shown by Cripps \& Matocha (1991). As observed in the biplot plot of main components, the low leaf concentrations of K were poorly correlated to maize productivity, justifying the incefficiency in K supply by sewage sludge and the decrease in productivity.

In our results, the $\mathrm{K}$ leaf concentrations did not follow a cumulative pattern. This variation can be justified by the availability of $\mathrm{K}$ in the soil, which underwent variations along the crop seasons in an antagonistic way with the $\mathrm{Ca}$ and $\mathrm{Mg}$, which provided competition for the retention sites.

The efficiency of supply of $\mathrm{Ca}$ and $\mathrm{Mg}$ by the sewage sludge was already verified by the chemical analysis (Table 2). The results obtained for $\mathrm{Ca}$ and $\mathrm{Mg}$ were similar to those of Tejada et al. (2016), in which working with sewage sludge treated in maize in the Extremadura region of Spain, found foliar $\mathrm{Ca}$ and $\mathrm{Mg}$ concentrations of up to 38.6 and $19.5 \mathrm{~g} \mathrm{~kg}^{-1}$, respectively, with application of $7.2 \mathrm{~L} \mathrm{ha}^{-1}$ of a compound the sewage sludge base containing $46.8 \mathrm{~g} \mathrm{~kg}^{-1}$ total $\mathrm{Ca}$ and $8.6 \mathrm{~g} \mathrm{~kg}^{-1}$ total $\mathrm{Mg}$. Thus, the agricultural potential of compounds with sewage sludge is evident for the supply of secondary macronutrients.

Regarding the results of foliar micronutrients, the risk of fertilization with sewage sludge should be considered, since their essentiality ranges are very narrow, which can easily lead to plant phytotoxicity. By the chemical analysis of the sewage sludge it is understood that the concentrations of micronutrients are changed every year of collection. It is essential to verify concentration rates. 
The results obtained in the PC1 of PCA refer to the understanding that the levels leaf $\mathrm{Ca}$ and Fe were inversely proportional to yield. Locations and times when maize showed high concentrations of these foliar nutrients were observed the lower grain yield. This fact can be justified by the doses of sludge applied and by the accumulation of these nutrients in the soil that have low mobility in the superficial layers. It was observed by the chemical analysis of the sewage sludge that the concentrations of $\mathrm{Ca}$ and Fe total were higher than $2 \mathrm{~g} \mathrm{~kg}^{-1}$ and $2000 \mathrm{mg}$ $\mathrm{kg}^{-1}$, respectively, being these nutrients available in large quantities according to established doses (Table 2).

The attributes SD, Zn, Mg and K, were not correlated in PC1 together with productivity, however, they showed that maize plants with greater stem diameter had the highest leaf concentrations of $\mathrm{Mg}$ and $\mathrm{Zn}$, and lower concentrations of $\mathrm{K}$. As for the leaf content of $\mathrm{K}$, this result can be justified by the low concentration of this nutrient in the sewage sludge, as previously reported, which is not a good supplier. In the physiological point of view the maize is very demanding in $\mathrm{K}$, its deficiency has direct action in the osmotic mechanism which can weaken the normal development of the plant.

The results show that successive applications of domestic sewage sludge gradually increase the macro and micronutrient foliar concentrations of maize. However, this increase should not be considered as a benefit to the plant, since the highest grain yields were observed in the first and second crops of the first agricultural year. Gill et al. (2014) also reported this variation in yield of sorghum over five years after successive applications of sludge. The authors attribute this behavior to their mineralization rate, which is generally higher in the first few years after their application.

Agreeing with such results, Tejada et al. (2016), Çelik et al. (2010), and Asumadu et al. (2012), observed that the application of organic extracts based on sewage sludge and mixtures of humic substances positively affects the absorption of macro and micronutrients by plants, possibly due to the high permeability of organic molecules in the epidermis and membranes of the plant, favoring of the ions connected to these molecules in the plant cell.

The application of domestic sewage sludge from small stations, such as that of the proposed system, should be investigated better. Given the low expected cost of production and its application, the practice can be truly profitable. In addition, the application of this compound via foliar should also be taken into account in order to gain a deeper understanding of the action of this biofertilizer for the crops and to provide practical recommendations for its use.

\section{Conclusion}

The leaf concentrations of $\mathrm{P}, \mathrm{K}, \mathrm{Ca}, \mathrm{Mg}, \mathrm{Fe}, \mathrm{Mn}$ and $\mathrm{Zn}$ in maize increase with successive applications of 30 and $40 \mathrm{Mg} \mathrm{ha}^{-1}$ of sewage sludge.

Successive applications of sewage sludge as the sole source of nutrients, cause reduction in plant height, weight and diameter of maize cob, number, mass and grain yield of maize, regardless of the dose applied.

Fertilization with sewage sludge for more than two consecutive crops, as the only source of nutrients, impairs maize productivity in a conventional cropping system.

The application of sewage sludge in the first harvest provides increases in maize grain yield and may be recommended instead of NPK mineral fertilizers at a dose of $23.68 \mathrm{Mg} \mathrm{ha}^{-1}$ in built fertility soils.

\section{References}

Asumadu, H., Adu-Dapaah, H., \& Obosu-Ekyern, S. (2012). Response of maize to organic foliar fertilizer and its economic implications to farmers in Ghana. International Journal of Agricultural Research, 7, 439-448. https://doi.org/10.3923/ijar.2012.439.448

Carlson, J. C., Anderson, J. C., Low, J. E., Cardinal, P., MacKenzie, S. D., Beattie, S. A., ... Buhay, W. M. (2013). Presence and hazards of nutrients and emerging organic micropollutants from sewage lagoon discharges into Dead Horse Creek, Manitoba, Canada. Science of the Total Environment, 445, 64-78. https://doi.org/ 10.1016/j.scitotenv.2012.11.100

Çelik, H., Katkat, A. V., Aşık, B. B., \& Turan, M. A. (2010). Effect of foliar-applied humic acid to dry weight and mineral nutrient uptake of maize under calcareous soil conditions. Communications in Soil Science and Plant Analysis, 42, 29-38. https://doi.org/10.1080/00103624.2011.528490

Cieślik, B. M., Namieśnik, J., \& Konieczka, P. (2015). Review of sewage sludge management: Standards, regulations and analytical methods. Journal of Cleaner Production, 90, 1-15. https://doi.org/10.1016/ j.jclepro.2014.11.031 
Cripps, R. W., \& Matocha, J. E. (1991). Effect of sewage sludge application to ameliorate iron deficiency of grain sorghum. Communications in Soil Science and Plant Analysis, 22, 1705-1715. https://doi.org/10.1080/ 00103629109368546

de Freitas Silva, E., Moitinho, M. R., Teixeira, D. D. B., Pereira, G. T., \& Júnior, N. L. S. (2014). Emissão de $\mathrm{CO}_{2}$ do solo associada à calagem em área de conversão de laranja para cana-de-açúcar. Engenharia Agrícola, 34, 885-898. https://doi.org/10.1590/S0100-69162014000500008

Gill, J. R., Burks, P. S., Staggenborg, S. A., Odvody, G. N., Heiniger, R. W., Macoon, B., ... Rooney, W. L. (2014). Yield results and stability analysis from the sorghum regional biomass feedstock trial. Bioenergy Research, 7, 1026-1034. https://doi.org/10.1007/s12155-014-9445-5

Gonzaga, M. I. S., Mackowiak, C. L., Comerford, N. B., da Veiga Moline, E. F., Shirley, J. P., \& Guimaraes, D. V. (2017). Pyrolysis methods impact biosolids-derived biochar composition, maize growth and nutrition. Soil and Tillage Research, 165, 59-65. https://doi.org/10.1016/j.still.2016.07.009

Greenhouse, S. W., \& Geisser, S. (1959). On methods in the analysis of profile data. Psychometrika, 24, 95-112. https://doi.org/10.1007/BF02289823

Guareschi, R. F., Perin, A., \& Gazolla, P. R. (2013). Produtividade de milho submetido à aplicação de ureia revestida por polímeros. Global Science and Technology, 6, 31-37. https://doi.org/10.14688/1984-3801. v06n02a04

Guimarães, A. B., \& Conte, M. L. (1997). Processo fito-pedológico para o tratamento de águas servidas. In Congresso de Iniciação Científica da UNESP, 9. Anais ... Jaboticabal: UNESP.

Guimarães, A. B., Breda, C. C., \& Leopoldo, P. R. (1999). Papel do Aguapé na despoluição de águas servidas no meio rural (Paper: SCA-45, p. 5). In Congresso Brasileiro de Engenharia Agrícola, 28. Anais ... Pelotas: SBEA.

Leopoldo, P. R., Guimarães, A. B., \& Breda, C. C. (1999). Tratamento de efluentes domésticos em zona rural através do uso de sistema com plantas aquáticas (Paper: SCA-19, p. 6). In Congresso Brasileiro de Engenharia Agrícola, 28. Anais ... Pelotas: SBEA.

Malavolta, E., Vitti, G. C., \& Oliveira, S. A. (1997). Avaliação do estado nutricional de plantas: Princípios e aplicações (2nd ed.). Piracicaba, SP: Potafós.

Mauchly, J. W. (1940). Significance test for sphericity of a normal n-variate distribution. The Annals of Mathematical Statistics, 11, 204-209. https://doi.org/10.1214/aoms/1177731915

Shapiro, S. S., \& Wilk, M. B. (1965). An analysis of variance test for normality (complete samples). Biometrika, 52, 591-611. https://doi.org/10.2307/2333709

SNSA (Secretaria Nacional de Saneamento Ambiental). (2015). Sistema Nacional de Informações sobre Saneamento: Diagnóstico dos Serviços de Água e Esgotos. Brasília, DF: SNSA/MCIDADES. Retrieved from http://www.snis.gov.br

Tejada, M., Rodríguez-Morgado, B., Gómez, I., Franco-Andreu, L., Benítez, C., \& Parrado, J. (2016). Use of biofertilizers obtained from sewage sludges on maize yield. European Journal of Agronomy, 78, 13-19. https://doi.org/10.1016/j.eja.2016.04.014

Trevisan, R. G., Freddi, O. D. S., Wruck, F. J., Tavanti, R. F. R., \& Peres, F. S. C. (2017). Variability of physical properties of soil and rice grown under cover crops in crop-livestock integrated system. Bragantia, 76, 1-10. https://doi.org/10.1590/1678-4499.596

van Raij, B., Cantarella, H., Quaggio, J. H., \& Furlani, A. M. C. (1996). Recomendação de adubação e calagem para o Estado de São Paulo (2nd ed.). Campinas, SP: Instituto Agronômico de Campinas. 


\section{Appendix}

\section{Tables of analysis of variance}

Appendix 1. Value of $\mathrm{W}$ obtained by the Mauchly sphericity test for sowing time factor $(\mathrm{T})$ and calculated $\mathrm{F}$ values for nutrient concentrations in maize leaves for the factors blocks, fertilization with sewage sludge and NPK fertilizer (SS) and maize sowing times with their respective interactions

\begin{tabular}{|c|c|c|c|c|c|c|c|c|c|c|c|}
\hline \multirow{2}{*}{ Factors } & \multicolumn{6}{|c|}{ Foliar macronutrients } & \multicolumn{5}{|c|}{ Foliar micronutrients } \\
\hline & $\mathrm{N}$ & $\mathrm{P}$ & $\mathrm{K}$ & $\mathrm{Ca}$ & $\mathrm{Mg}$ & $\mathrm{S}$ & $\mathrm{B}$ & $\mathrm{Cu}$ & $\mathrm{Fe}$ & $\mathrm{Mn}$ & $\mathrm{Zn}$ \\
\hline Blocks & $1.9^{\mathrm{ns}}$ & $3.2^{\mathrm{ns}}$ & $2.9^{\mathrm{ns}}$ & $1.3^{\mathrm{ns}}$ & $2.6^{\mathrm{ns}}$ & $2.5^{\mathrm{ns}}$ & $0.8^{\mathrm{ns}}$ & $0.4^{\mathrm{ns}}$ & $0.5^{\mathrm{ns}}$ & $0.9^{\mathrm{ns}}$ & $1.0^{\mathrm{ns}}$ \\
\hline SS & $1.8^{\mathrm{ns}}$ & $7.3^{*}$ & $5.9^{*}$ & $1.5^{\mathrm{ns}}$ & $0.6^{\mathrm{ns}}$ & $6.0^{*}$ & $1.1^{\mathrm{ns}}$ & $0.6^{\mathrm{ns}}$ & $0.6^{\mathrm{ns}}$ & $34.0^{*}$ & $17.9^{*}$ \\
\hline $\mathrm{T}$ & $127.6^{*}$ & $279.1^{*}$ & $127.5^{*}$ & $45.9^{*}$ & $1148^{*}$ & $69.2^{*}$ & $137.8^{*}$ & $3.3^{\mathrm{ns}}$ & $150.1^{*}$ & $144.6^{*}$ & $205.6^{*}$ \\
\hline $\mathrm{SS} \times \mathrm{T}$ & $2.0^{\mathrm{ns}}$ & $1.9^{\mathrm{ns}}$ & $2.0^{\mathrm{ns}}$ & $6.7^{*}$ & $9.8^{*}$ & $2.0^{\mathrm{ns}}$ & $2.4^{*}$ & $0.6^{\mathrm{ns}}$ & $1.4^{\mathrm{ns}}$ & $24.8^{*}$ & $13.2^{*}$ \\
\hline W-Mauchly & $0.13^{*}$ & $0.02^{*}$ & $0.33^{\mathrm{ns}}$ & $0.05^{*}$ & $0.09^{*}$ & $0.06^{*}$ & $0.73^{\mathrm{ns}}$ & $0.00^{*}$ & $0.01^{*}$ & $0.20^{*}$ & $0.27^{*}$ \\
\hline Overall mean & 26.41 & 3.09 & 16.22 & 6.51 & 3.87 & 2.30 & 12.78 & 16.98 & 175.06 & 65.97 & 48.48 \\
\hline CV 1 & 11.44 & 23.20 & 10.31 & 24.81 & 24.57 & 22.97 & 20.11 & 18.08 & 19.24 & 22.35 & 15.05 \\
\hline CV 2 & 15.04 & 32.69 & 14.72 & 34.99 & 36.54 & 65.21 & 15.30 & 30.86 & 37.42 & 23.60 & 25.94 \\
\hline
\end{tabular}

Note. $\mathrm{N}, \mathrm{P}, \mathrm{K}, \mathrm{Ca}, \mathrm{Mg}, \mathrm{S}\left(\mathrm{g} \mathrm{kg}^{-1}\right) ; \mathrm{B}, \mathrm{Cu}, \mathrm{Fe}, \mathrm{Mn}, \mathrm{Zn}\left(\mathrm{mg} \mathrm{kg}^{-1}\right) ; \mathrm{CV} 1$ and $\mathrm{CV} 2$ correspond to the coefficients of variation (\%) for factors SS and T, respectively, ${ }^{*}$ significant and ns not significant for the $\mathrm{F}$ test at 0.05 probability.

Appendix 2. Value of $\mathrm{W}$ obtained by the Mauchly sphericity test for the sowing time factor $(\mathrm{T})$ and the $\mathrm{F}$ values calculated for the biometric parameters of the maize for the factors blocks, fertilization with sewage sludge and NPK fertilizer (SS) and times of maize sowing with their respective interactions

\begin{tabular}{|c|c|c|c|c|c|c|c|c|c|}
\hline \multirow{2}{*}{ Factors } & \multicolumn{9}{|c|}{ Productive parameters ${ }^{1}$} \\
\hline & $\overline{\mathrm{PH}}$ & NL & SD & MW & ML & MD & $\mathrm{NG}$ & GM & GY \\
\hline Blocks & $0.64^{\mathrm{ns}}$ & $1.95^{\mathrm{ns}}$ & $1.13^{\mathrm{ns}}$ & $0.62^{\mathrm{ns}}$ & $0.99^{\text {ns }}$ & $1.3^{\mathrm{ns}}$ & $3.05^{\mathrm{ns}}$ & $0.69^{\mathrm{ns}}$ & $1.41^{\mathrm{ns}}$ \\
\hline SS & $19.2^{*}$ & $15.3^{*}$ & $15.7^{*}$ & $9.3^{*}$ & $7.9^{*}$ & $6.1^{*}$ & $10.2^{*}$ & $9.3^{*}$ & $8.7^{*}$ \\
\hline $\mathrm{T}$ & $120.9^{*}$ & $40.8^{*}$ & $12.01^{*}$ & $142.3^{*}$ & $41.6^{*}$ & $15.2^{*}$ & $48.02^{*}$ & $155.9^{*}$ & $82.34^{*}$ \\
\hline $\mathrm{SS} \times \mathrm{T}$ & $3.18^{*}$ & $3.19^{*}$ & $3.23^{*}$ & $3.28^{*}$ & $1.56^{\mathrm{ns}}$ & $0.73^{\text {ns }}$ & $3.5^{*}$ & $3.15^{*}$ & $1.69^{\mathrm{ns}}$ \\
\hline W-Mauchly & $0.22^{*}$ & $0.88^{\mathrm{ns}}$ & $0.5^{\mathrm{ns}}$ & $0.64^{\mathrm{ns}}$ & $0.84^{\mathrm{ns}}$ & $0.11^{*}$ & $0.73^{\text {ns }}$ & $0.62^{\mathrm{ns}}$ & $0.57^{\mathrm{ns}}$ \\
\hline Average & 172.7 & 13 & 2.41 & 5.67 & 16.63 & 49.31 & 520 & 4.62 & 8.14 \\
\hline CV 1 & 10.39 & 3.82 & 4.87 & 5.30 & 10.46 & 10.77 & 9.75 & 4.37 & 6.05 \\
\hline CV 2 & 13.35 & 4.83 & 2.58 & 4.19 & 13.31 & 15.99 & 10.23 & 4.68 & 8.11 \\
\hline
\end{tabular}

Note. PH: plant height (cm), NL: number of leafs (n), SD: stem diameter (cm), WM: maize cob weight (g), ML: maize cob length $(\mathrm{cm})$, MD: maize cob diameter $(\mathrm{mm})$, NG: number of grains in maize cob (n), GM: 100 grains mass (g), GY: grain yield ( $\left.\mathrm{Mg} \mathrm{ha}^{-1}\right)$; CV 1 and CV 2 correspond to the coefficients of variation (\%) for factors SS and $\mathrm{T}$, respectively, ${ }^{*}$ significant and ns not significant for the $\mathrm{F}$ test at $5 \%$ probability.

\section{Copyrights}

Copyright for this article is retained by the author(s), with first publication rights granted to the journal.

This is an open-access article distributed under the terms and conditions of the Creative Commons Attribution license (http://creativecommons.org/licenses/by/4.0/). 